\title{
Child-Rights Education - Building Capabilities and Empowerment Through Social Constructivism
}

\author{
Kathleen Manion, $\mathrm{PhD}$ \\ Associate Professor \\ School of Humanitarian Studies \\ Royal Roads University \\ Kathleen.Manion@RoyalRoads.ca \\ Shelly Jones, $\mathrm{PhD}$ \\ Professor \\ College of Interdisciplinary Studies \\ Royal Roads University \\ Shelley.12jones@RoyalRoads.ca
}

\begin{abstract}
Children have the right to a voice, to education, and to education about their rights, as outlined in Article 12 and Article 29 of the United Nations Convention on the Rights of the Child. Child rights-based education can support children to be empowered with critical agency and exposed to connection to the wider world, better equipping them to become young global citizens and act in ways that demonstrate empathy and commitment to diversity, dignity, and equality. To obtain this goal, education systems must be aligned to foster these attributes and empower children to develop and exercise the capabilities that will best serve them in childhood as well as adulthood. This paper considers how we can support the empowerment and capabilities development of children through child rights-focused education using an integrated framework of empowerment, capabilities (Sen, 1999), and social constructivist (Vgotsky, 1978) education. Building on the foundations laid in the development and evolution of children's rights, setting out the theoretical underpinnings and drawing on a case study of a rights-based education project, this paper will consider how rights-based education can be feasible and beneficial.
\end{abstract}


Key words: children's rights; rights and responsibilities; social constructivist education; child participation; Uganda, Canada 


\section{Introduction}

Children have the right to learn about their rights; they also have the right to be supported in exercising those rights so that they can participate in decision-making that will impact their futures. Article 12 of the United Nations Convention on the Rights of the Child (UNCRC) states children have "the right to express those views freely in all matters affecting the child, the views of the child being given due weight in accordance with the age and maturity of the child" (UNICEF, 1989, Article 12). Nevertheless, "the vast majority of children remain in the dark about their rights and schools remain largely oblivious to the need for implementing the full range of children's education rights" (Covell et al, 2017, p. 296). Little research or literature exists that explores how children's rights can be embedded in meaningful, culturally appropriate, and age-appropriate ways in schools to promote children's awareness of their rights, especially in early grades.

Greta Thunberg and Malala Yousafzai, two young people demonstrating visionary leadership, show what children can accomplish when empowered with capabilities (Sen, 1999) functioning, freedoms, and agency - that enable their voices to be heard. However, attention given to the voices of youth should not be exceptional: the UNCRC states that all children have the right to be educated about their rights and to participate in decisions that impact them. Children need to understand that they have agency and that they are connected to a wider global community, as young global citizens, and must be recognized and respected as such. The world that they will inherit will require global, collaborative decision-making competencies and the strength and resilience to tackle the myriad, complex issues that need to be addressed to create a better, sustainable planet for all.

The recent COVID-19 pandemic and the intensifying climate crisis have revealed the kinds of competencies that children will need in adulthood to cope with precarious events and conditions in the world. The future will require unprecedented collaboration of populations, states, and agencies to develop effective global responses to dangerous conditions - such as pandemics and climate change. We will need to think and act in ways that are genuinely rooted in empathy and commitment to diversity, dignity, and equality to bring about transformational change that benefits the well-being of everyone. To achieve this, we must realign our education systems to foster these skills and empower children to develop the capabilities that are going to best serve them. 
Thus, our key objective for this paper is to contribute to the discussion of sound pedagogical practices that promote child-rights education. By building on the foundations laid in the development and evolution of children's rights, and weaving this together with the theoretical underpinnings of social constructivism (Vgotsky, 1978), capabilities (Sen, 2000; Nussbaum, 2003), and empowerment (Alsop et al, 2006) we propose an educational approach to child rights that will enable children to both understand their own rights and responsibilities in their childhood lives as well as prepare them to meet the demands they will face in their adult lives.

In exploring the efficacy and application of such a model, we consider a comparative study we conducted in 2018 (Jones, 2019; Jones et al, 2018) that engaged children and educators in Western Canada in learning about children's rights. We used the Child Thrive program, developed by the International Institute of Child Rights and Development (IICRD). Child Thrive engages children through age-appropriate, creative, collaborative, play- and arts-based activities that encourage children to explore and reflect on their own rights and responsibilities as well as those of all children in the world. This study focused on two countries with quite different contexts for child rights and education: Canada and Uganda. The diversity of contexts lends to an exploration of how this theoretical application of a pedagogical model of rights-based education may be adapted to local diverse contexts. Both countries have ratified the UNCRC and have policies that support promotion, protection, and fulfilment of children's rights, including a child's right to be educated on rights, but Canada represents a high income country while Uganda is a low income country. Both countries grapple with their inherited colonial legacies and both include broad cultural diversity. Uganda has a young and rapidly growing population. The population is rural, and the economy is dominated by agriculture. Canada is the second largest country in the world with an older population, largely scattered along its southern border. It has a mixed economy. Canada tends to adopt a more individualistic approach to rights identification and realisation, whereas Uganda approaches a more collective approach to rights understanding.

Although we will refer to findings and observations based on our 2018 study, this paper explores a much broader perspective on the role of the theoretical concepts implied in building rights-based approaches more centrally into curriculum and discusses ways to fill research gaps in child rights-focused education. 


\section{Human Rights and the UNCRC}

The Universal Declaration of Human Rights was brought into force in 1948 (Normand \& Zaidi, 2008). This was not the first human rights instrument, but it significantly shifted global conversations in innovative ways. This document gave birth to more specific and binding human rights treaties, including the UNCRC which opened for signature in 1989. This far-reaching agreement was met with unprecedented acceptance around the world; it has been signed and ratified by all but one of the world's nations (Butler, 2012). Although it has been more than 30 years since it was introduced, it is still shaping children's rights. While some of its content remains aspirational, it is an important reminder of what we collectively strive for. However, children around the globe remain victim to various forms of maltreatment, in all countries and within all socioeconomic and cultural contexts. Mass violence, poverty, inequality, insecurity, famine, disease, civil and political unrest violate the most basic of children's rights (Hanlon \& Christie, 2016). The UNCRC provides a basis for advocates, including children themselves, to identify and call for better opportunities to enact those rights.

The values espoused in the UNCRC align with other international human rights instruments, but they further recognise the special status of people under the age of 18 . The four fundamental families of children's rights include the right to survive and develop; the best interests of the child; nondiscrimination; and the right to be heard. These core families of rights can support myriad and diverse educational aspirations and augment a wide range of curricular objectives and support an appreciation of children's wellbeing as expressed through relational commitments and the need for identity, dignity, freedom, equality, and belonging.

Children's rights sit within a broader framework supporting children's wellbeing. Most agree about the value of supporting children's well-being, but actions of states and agencies belie a lack of commitment to real action or dedicated resources towards this end (Freeman, 2011; Save the Children, 2008; Lundy, 2012; Unger, 2009: Hughes, 2010). Many policies, practices, and processes are geared towards helping children thrive, yet these are often siloed, and lessons learned in these processes are not widely shared (NRC \& Institute of Medicine, 1996; NRC et al, 2015). Focusing on children's rights offers a platform to better integrate processes with a childcentred approach. Understanding those rights is a first step in their attainment. Calls to ensure that children are taught about their rights in schools and other settings have been made to support a good basis for citizenship building (Burridge \& Chodkiewicz, 2017). 
General Comment 1 to the UNCRC interprets Article 29 (1) to foster human rights education, including the content of human rights treaties, but also how they can be implemented in practice and made meaningful at home, in school, and in the community. Verhellen (1994) proposed that children's rights discussions fall into three areas: progressively achieved children's rights; the role of the education system to provide circumstances that rights can be enacted for all children including those experiencing vulnerabilities; and through rights-based education. Covell et al (2017) noted that the UNCRC monitoring system consistently requires states to better incorporate rights education into the curriculum and teacher training but notes that few children have been educated about their rights and have limited understanding of the Convention (Howe \& Covell, 2013). Furthermore, while the education system has failed to implement rights education, "research studies show that where schools have fully implemented child rightsconsistent education, the outcomes have been unambiguously positive" (Covell et al, 2017, p. 300).

\section{Children's rights in Canadian and Ugandan contexts}

Acknowledging the need to learn how to teach children about their rights in ways that facilitate their understanding of the importance and relevance of those rights in the particular contexts within which they live, we conducted a study within two very diverse contexts: rural Southwestern Uganda and a city in Western Canada. Concerns relating to children's rights in each of the countries as well as site-specific contexts are considered below.

\section{Uganda Child-Rights Overview}

Uganda has made important commitments to children's rights and well-being. Uganda's National Child Participation Strategy (Uganda Ministry of Gender, Labour \& Social Development, 2017) endorsed a mandate to view children as stakeholders and support their participation and visibilities in plans, programs, and policies and included the voices of 250 children (Uganda Children's Portal, 2019). Positively, the Universal Periodic Review (United Nations General Assembly (UNGA), 2016) highlighted the national plan to redress child marriage and teen pregnancies and an improving rate of gender parity in schools. The Children (Amendment) Act No.19 (2016) also brought positive action with additional protections against violence against children and harmful customary practices and employment and the establishment of the National Children's Authority. In addition, Uganda has ratified several key 
international rights instruments, including the Optional Protocol to the UNCRC on the Involvement of Children in Armed Conflict.

However, there remain a number of areas of concern with respect to the implementation and upholding of child rights. The Universal Periodic Review (UNGA, 2016) noted high levels of child labour, increasing numbers of children homeless and living on the streets, high levels of violence against children, and five million unregistered children. Humanium (2019) reported that 36 percent of children (aged 5-14) financially support themselves or their family. The report regarding the Optional Protocol to the UNCRC on the Sale of Children, Child Prostitution and Child Pornography, demonstrated a lack of actual child engagement with laws, policies, and initiatives that impact them. Despite the 1997 law against corporal punishment of children at school "the use of violence against students is widespread" (Devries et al, 2013, p. 1; see also Jones, 2008). Children are also punished by beating at home (Boydell et al, 2017).

There are also many gender-related disadvantage and rights violations. Girls are typically expected to undertake more household duties than are boys, which is not only unfair in principle but also negatively impacts their available time for studying (Detzberger \& Le Mar, 2018; Jones 2008, 2011; Kakuru, MOES, 2015; Stobenau et al 2015). Even at school, girls are often assigned roles that they are expected to perform at home, such as washing the teachers' dishes, serving tea, and taking care of teachers' young children while boys are given time to study or play sports (Jones, 2008, 2019). Boys' education is still largely prioritized over that of girls and if schoolrelated costs such as uniforms and supplies for all children in the family are beyond the financial means of the parents/guardians, typically the choice will be made to support the boys' education at the expense of the girls' (Stobenau et al 2015). Long distances to school are more problematic for girls than for boys in contexts where it is culturally inappropriate for girls to ride bicycles or bicycles are purchased primarily for boys; girls can spend several hours a day walking to and from school, while boys with bicycles have a much shorter commute time (Jones, 2008). Girls are also at risk of sexual assault during their commute to and from school (Jones, 2008, 2011; MOES, 2015; Rwanyonga et al, 2009) and are even at risk of sexual abuse and assault as well mental, emotional, and physical violations at school by male teachers and students (Jones, 2011; MOES, 2015; Muhanguzi, 2011). Forced and child marriages for girls (Wodon et al, 2016) and early pregnancies (Ochen et al, 2019; Wodon et al, 2016) are also prevalent in Uganda, limiting girls' opportunities for education, employment, and numerous other opportunities in life. 
Furthermore, Uganda is a patriarchal society with expectations that girls and women should obey and defer to boys and men; this encourages boys to participate more actively and vocally at school, at home, and in their communities than girls (Kakuru 2006; Mirembe \& Davies, 2001; Mlama et al, 2005; MOES, 2015).

In the region where this research was conducted, 53 percent of the population is under 18 years and issues of concern include 13 percent of school-age children are not attending school; high birth (6 percent) and marriage (6.5 percent) rates for girls under 18 ; high percentage of households lacking safe water (31 percent), electricity (83 percent), a “decent dwelling” (96 percent), and any kind of toilet facilities (5 percent); more than five kilometres to health (10 percent) and police services (23 percent) (Uganda Bureau of Statistics, 2017).

\section{Canada Child-Rights Overview}

Despite Canada's strong economic development, good reputation for enacting human rights, and early adoption of the UNCRC, it has mediocre results with respect to addressing child poverty, child mental health, child obesity, and educational standards. Canada has poor rates of child happiness and safety (UNICEF Canada, 2016, 2018, 2019), and it has fared poorly across UNICEF's Sustainable Development Goals measurements: ending hunger (37 out of 41) and poverty (32 out of 41), promoting child health and well-being (29 out of 41), and having peace, justice, and strong institutions (37 out of 41) (UNICEF (OR), 2017). UNICEF Canada (2018) ranked Canada 9th overall but 22nd for preschool enrolment, 24th in food security and child poverty, 27th for bullying, and 29th for obesity. It also has inequality, with some children experiencing high levels of poverty, with 9 percent living in families without enough income to meet their basic needs and 20 percent living in relative poverty (UNICEF Canada, 2019). Children in Canada also report experiencing high levels of violence (28 percent of children experience fighting, 27 percent of children experience bullying regularly, and 25 percent of children experience violence in the home). There are also concerning environmental factors that impinge on their rights. For instance, 11 percent of children live in areas that have had water boil advisories and many live in cities that have air quality that is below a safe limit (UNICEF Canada, 2019). While Canada has a high expenditure on education, compared to other OECD countries, spending on children in general is low (UNICEF, 2017). Rates of success across indicators on health, well-being, and poverty are worse for Indigenous children in Canada (UNICEF, 2017; Macdonald \& Wilson, 2013). Canada's legislative framework favours a 
Western approach to child well-being and undermines Indigenous perspectives which disadvantage Indigenous children, leaving them more vulnerable to lacking basic needs and a swath of other rights (Blackstock et al, 2020).

\section{Theoretical considerations}

We suggest that child rights-based education in the early years has the potential to cultivate empowerment that will help children position themselves in their communities and the larger world, develop a sense of citizenship, and participate in democratic practices that promote equality, social justice, and respect for every human being. We acknowledge that "empowerment" is a contested term (Ibrahim \& Alkire, 2007), but we align our understanding of it with Alsop, Bertelsen, and Holland's (2006) definition of empowerment as “a group's or individual's capacity to make effective choices ... and then transform those choices into desired actions and outcomes" (p. 10). We link this understanding of empowerment to the capabilities approach (Sen, 1999, 2005; Nussbaum, 2003, 2011) which posits that functionings (what one can do or be), freedoms (what one is free to do or be), and agency (the actions one takes) are constitutive of capabilities leading to "the freedom to achieve various lifestyles" (1999, p. 4). Rights and responsibilities both inform and are informed by empowerment and capabilities. Providing children with opportunities to learn about rights, support well-being, and encourage agency provides a platform for "critical agency" (Sen \& Dreze, 2002; see also Hart \& Brando, 2018) and "human flourishing" (Sen, 1999).

Pedagogical practices can be situated and understood within global education and capabilities frameworks. The UNCRC (1989) preamble states "the child, for the full and harmonious development of his or her personality, should grow up in a family environment, in an atmosphere of happiness, love and understanding" and should be prepared for a "responsible life in a free society, in the spirit of understanding, peace, tolerance, equality of sexes, and friendship among all peoples, ethnic, national and religious groups and persons of indigenous origin" (UNCRC, 1989, Article 29d). As educators who aspire to achieve this, we believe a social constructivist approach to education (Vgotsky, 1978) is well aligned.

Lev Vgotsky (1896-1934), considered to be the founder of social constructivism, asserted that "social constructivist epistemology locates knowledge, not as an objective, contextdevoid discovery, but rather as a contextually-driven intrapersonal creation" (Adams, 2006, p. 254). Based upon social interactions, that should lead to social change (Young, 2007). With 
guidance from and in collaboration with more knowledgeable others (MKOs) - adults or other children with more experience and knowledge in particular areas - children should ideally be exposed to a more expansive understanding of rights and responsibilities for all children everywhere and be encouraged to reflect upon their own lives and situate their unique experience with rights met or unmet and responsibilities executed or not.

The contexts in which knowledge is created are also significant. All individuals in a classroom - educators as well as children - bring their diverse home, cultural, and often linguistic capital to the classroom which frames how they will coconstruct new knowledge with others (Sutherland et al, 2004). The classroom can be a site of discordant ideological, cultural, and epistemological perspectives. A social constructivist model of education seeks to open dialogue and relationship-building to acknowledge and embrace difference and establish common ground.

For children, the different realms of school and home can be particularly acute. "School knowledge" and "home/cultural knowledge" often collide, forcing children to ally themselves with one or the other viewpoint or continuously dance between the two. But a social constructivist learning environment intentionally asks the child to draw upon and value their learning from their home and community and to find connections (Adams, 2006). Learning can thus be contiguous and relevant to the multiple realms within which the child interacts and develops. This is all the more important in contexts where children lack access to "schooling as usual" as, for example, when schools have closed due to a life-threatening situation (e.g., the COVID-19 pandemic) and schooling is expected to happen in the home, guided by parents/guardians.

Social constructivism has important implications for pedagogy. The coconstructed knowledge drawn from the everyday and the theoretical, and through interactions with others, requires a pedagogical approach that is learner-centred, inquiry-based, reflective, critical, experiential, collaborative, and receptive to a wide range of perspectives (Adams, 2006; Kalina \& Powell, 2009; Young, 2007). The social constructivist classroom is a space of active engagement, discussion, social interactions, and experiential learning (Kalina \& Powell, 2009, p. 248).

In social constructivist learning environments, teachers and students work closely together both in the creation of knowledge and the sociocultural nature of the classroom 
environment (Silcock, 2003). Rather than position themselves as holders and dispensers of knowledge, teachers assume roles as MKOs that have more advanced understanding and skills related to the content or process and thereby scaffold (or support) structured, intentional, incremental learning through age-appropriate and experiential concepts and activities to encourage cocreation of knowledge with children (Adams, 2006, p. 249).

A social constructivist classroom also promotes peer-teaching and learning through zones of proximal development (ZPD), defined by (Vgotsky, 1978) as "the distance between the actual development level as determined by independent problem solving and the level of potential development as determined through problem solving under adult guidance with peer collaboration with more capable peers" (p. 86 ). Children may be unable to independently acquire skills and/or knowledge but they can obtain this under the guidance of a teacher/adult/MKO or a more knowledgeable peer. These teaching interactions amongst peers will empower children to become independent, where "knowledge constructed is an indication of how the world might be" (Adams, 2006, p. 246).

Integrating specific elements of the UNCRC fits well under this framework. Article 12 identifies the right to participation and Article 31 the right to play. Lundy (2007) suggests that to imbibe Article 12, children need a safe space for their voice to be heard, support to have their voice heard, someone to actively hear (or see) their opinions and ideas, and to have their ideas acted upon and influence change. Further, experts knowledgeable about optimal child development expound the importance of play for children's intellectual, social, physical, and emotional development (e.g. Ashiabi, 2012; Lester \& Russell, 2008, 2010; Vygotsky, 1978; Piaget, 1962). Educational resources concerned with children's rights are widely available, yet there is limited uptake by educators and seemingly a lack of understanding how these resources can be effectively used and implemented.

We argue, therefore, that social constructivism, which incorporates age-appropriate, multimodal, and knowledge-scaffolding resources, as well as guidance, collaboration, and inquiry with peers and MKOs best supports meaningful child-rights education that will enable children to flourish and actively participate in important decisions. The few studies that have been undertaken in this area, including our own (Manion \& Jones, 2019; Jones et al, 2019; Kones \& Manion, 2019) have noted that a social constructivist approach child rights-focused 
education supports children's deep understanding of the relevance and importance of rights of themselves and of others (Ruiz-Casares et al, 2017; Tibbets, 2002).

\section{Children's rights and research}

Undertaking research with children has numerous ethical considerations. We carefully adhered to all research ethics requirements which involved clearance at RRU, as well as Makerere U and the UNCST in Uganda. We prepared detailed (and translated, where necessary) explanations of the research project which were presented both in text and orally and obtained consent from parents of the children involved and assent from the children in addition to consent from all teachers involved. In the dissemination of our research and findings the safety and wellbeing of the children involved has always been prioritized.

\section{Case Study - An example of child-rights education}

To explore one approach to embedding rights-based education, we turn to a case study. A Canadian initiative called Child Thrive, delivered by IICRD, has been providing child-rights workshops in elementary schools in Western Canada since 2014. The program has provided one hour to one and a half hour workshops with students in various elementary schools between kindergarten and grade five several times a year. These are hands-on, arts-based, learner-centred workshops that explore what child rights mean and how they impact and protect children through a) developing cross-sectoral connections to advance challenging issues, such as bullying, child well-being and mental health; b) sharing children's perspectives on rights with key practitioners and decision-makers; and c) cultivating positive relationships, behaviours, and strategies among children, parents, and practitioners. We introduced the workshops in rural Uganda in 2018.

To further understand children's perspectives on rights and the rights-based approaches we conducted a comparative, participatory action research (PAR) study (Reason, \& Bradbury, 2006) in 2018 that engaged Primary 1 schoolchildren from rural south-central Uganda and Grade 1 schoolchildren in urban Western Canada who were participating in the Child Thrive workshops. The play- and art-based approach (Biddle, 2017) incorporated children's ideas (Brady et al, 2015) and aimed to gain a better understanding of how children interpreted their own rights and responsibilities in two different global contexts. The purpose was to cultivate awareness that all children in the world share the same rights enshrined in the UNCRC and to arrange for the children in Uganda and Canada to share their perspectives and encourage them to 
ask questions of each other. The research methods drew on field observation, structured playbased activities and discussions, and analysis of workshop artifacts including postcards to political leaders (noted below) on rights and other artwork.

PAR with children is a growing methodological area and is in alignment with Article 12 of the UNCRC that supports children to develop awareness, agency, and voice in political processes that impact their lives (Jones \& Walker, 2011). Torre and Fine (2006) posit that PAR involving youth represents a paradigmatic shift from research on youth to research with youth, requiring engaging, age-appropriate, and participative methods that ensure coconstruction of meaning (Christensen \& James, 2000; Christensen \& Prout, 2002; Collins \& Wright, 2019; Currie \& Heykoop, 2011; Jones \& Walker, 2011; Shamrova \& Cummings, 2017). Our qualitative (Mason, 2002) research involved the investigation of active engagement with educational practices involving children and educators to understand how to effectively operationalize child rights-focused education involving "participants conducting inquiry into their own practices in order to improve teaching and learning, practices and programs ... the researchers are participants in the activity being investigated" (Hines et al, 2016, n.p.).

The PAR approach allowed us to explore children's rights through the lived experiences of children and to understand how child-rights education might be integrated in classrooms in diverse global settings while also meeting curricular objectives. In both contexts, the classroom teachers and researchers/facilitators (authors) codeveloped and cotaught the lesson, which involved the children in storytelling, puppetry, artwork, games, and writing postcards to key political figures to teach the children about rights and responsibilities, the difference between needs and wants, and the allied concept of belonging. We used child-friendly resources, communication, listening, and imaginative pedagogical approaches. The children in the two classes explored and shared their ideas with each other and with the adults who facilitated the sessions. The sessions were between one hour and three hours, and they included multiple sessions to facilitate correspondence between the two classes. This allowed students in Canada and in Uganda to share their perspectives with one another. This PAR gathered the children's ideas in two classes, in words and artwork, about what they understood and what mattered to them regarding child rights. The different contexts of the two communities offered some ability to compare their insights on rights as expressed in the UNCRC. 
The data were coded and analysed iteratively by the researchers (Creswell, 2008; Grbich, 2013; Creswell \& Creswell, 2018). This triangulated design analysis approach (Cresswell, 2008) allowed us to capture a diverse scope of relevant and meaningful data so that our findings were robust enough to offer "thick description" (Geertz, 1973) with respect to paths of possibility for effective and empowering child-rights education. The analysis first focused on what children identified as rights and then on the themes that emerged from the dialogue the children engaged in. This analysis process was member-checked with the teachers to incorporate contextual nuance (Miles \& Huberman, 1994).

This research required a high standard of ethical practice, ensuring ongoing informed consent/assent of children and their guardians, careful handling of privacy of information, and child safeguarding. To ensure this, an ethical review was conducted and approved in 2018 by the Royal Roads Ethical Review, Makerere University in Kampala, Uganda, and the Uganda National Council for Science and Technology.

\section{Discussion - Considering the Findings from the Case Study}

In redressing the notion that children are often under-listened to, these meaningful and effective child-rights workshops illustrated a way of engaging children's participation in their learning about their rights. This cultivated empowerment and capabilities which supported the children's deepened notions of citizenship and participation in democratic real-life approaches.

All the teachers and facilitators in this project were committed to introducing the concept of child rights, the UNCRC, and facilitating class discussions with the understanding that children's ideas would direct discussions. This approach enabled adults to gain insights into the children's perspectives while also supporting their learning. As MKOs, the teachers and facilitators provided resources and activities that scaffolded the children's learning.

In both countries, the workshop opened with an introduction to the concept of children's rights and the UNCRC. This was aided with a puppet - "Giggles" in Canada, "Nunu" in Uganda - who suggested they had come to Planet Earth to learn about children's rights. Giggles and Nunu asked the children to share their thoughts and ideas about children's rights so they could take these ideas back to their home planets. Giggles and Nunu served to build a dialogic relationship between the children and the MKOs and create an environment of cocreation of knowledge. 


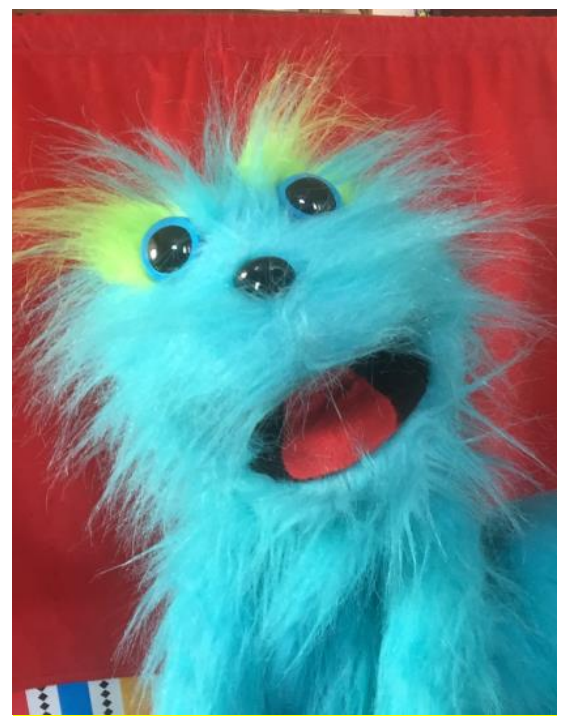

Figure 1 - Giggles

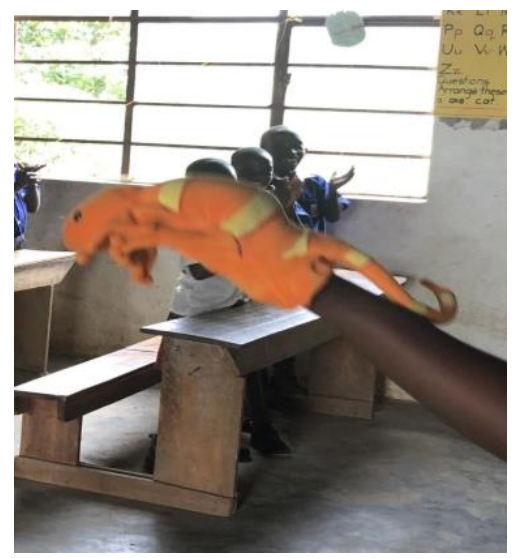

Figure 2 - Nunu

A colourful, age-appropriate children's storybook was used by MKOs to further integrate more complex learning about child rights and the UNCRC. This required the teacher/MKO in Uganda to translate the book into the local language, Luganda, using illustrations that represented contextually relevant ideas for children living rural Uganda. This aligns with the social constructivist acknowledgement of the importance of culture and children's background knowledge to new knowledge acquisition. 


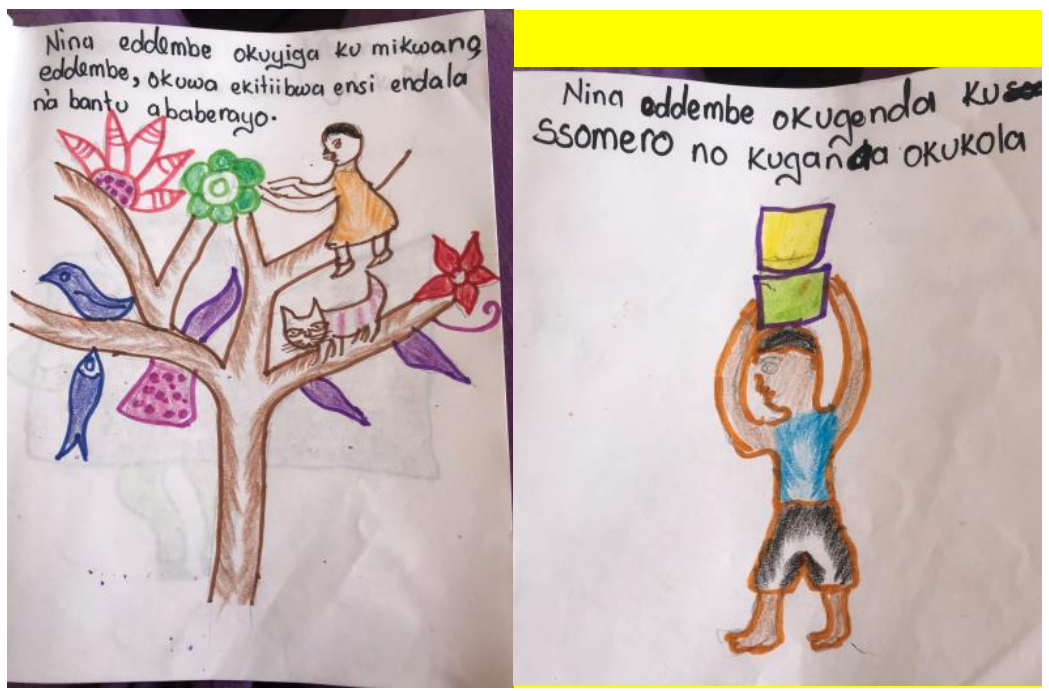

Figure 3 - Translated Children's Rights Book in Luganda

The children in both Canada and Uganda were then asked to share what rights and responsibilities they have in school and at home and which ones were important to them. They were also asked to share who in their lives supports them to protect their rights. The MKOs facilitated these discussions which encouraged the children to make connections between children's rights and their own lives. This supported children's conscientization (Freire, 1972) of rights by developing an understanding of tangible relevance to them.

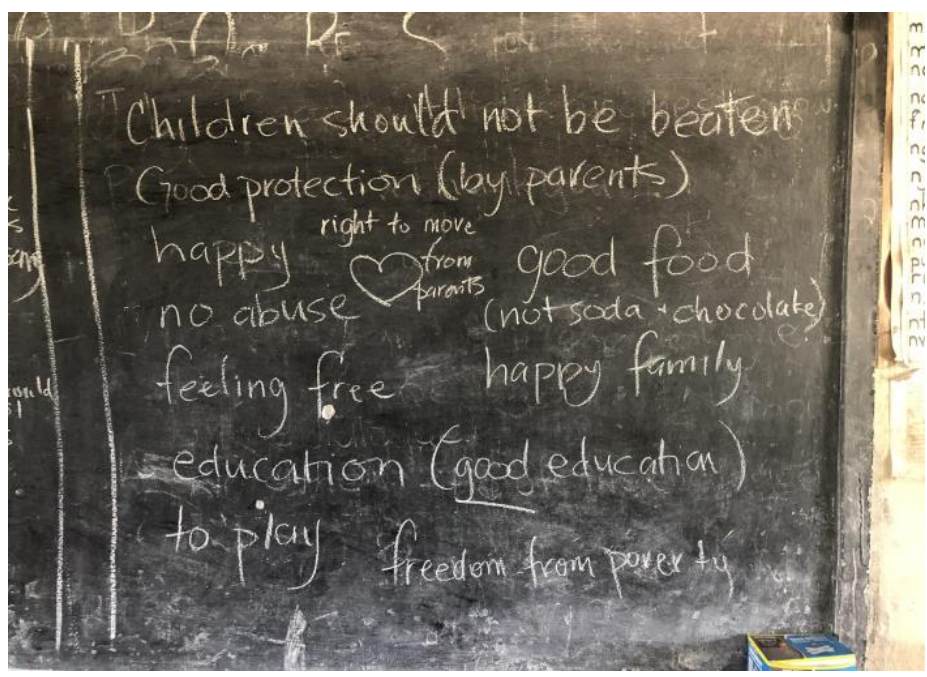

Figure 4 - Rights that are important to me 
The children in Uganda and Canada identified a remarkably similar list of rights. In descending order, children in Uganda most cited the following rights: play, home, food, education/school, travel (e.g. bus), friends, and family. The Canadian children expressed a slightly broader range including the following, in order: play, friends, home, family, food, clean water, art (expression), education/school, love, clothes, clean air/environment. This illustrated their integrated, contextualised understanding of children's rights.

The MKOs further scaffolded the learning by providing play-based activities that explored different components of rights. One activity involved "fishing for rights" where children used a fishing rod with magnetised fish (adapted from Equitas, 2008) to catch a right (also magnetized). Then they were asked to identify responsibilities that corresponded to that right. These included the right to be respected, with the responsibility to respect others; the right to be safe and the responsibility to help keep others safe; the right to education and the responsibility to study hard; the right to love and the responsibility to be loving towards others.

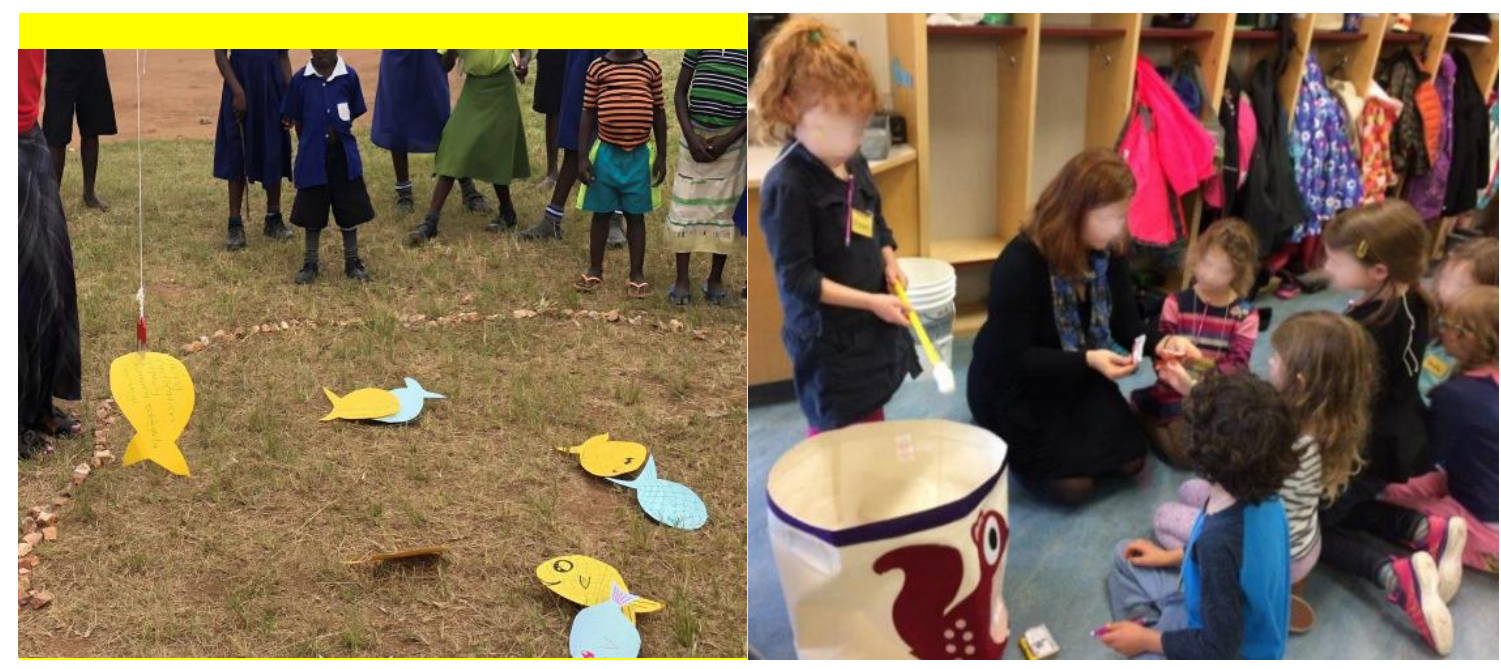

Figure 5 - Fishing for Rights, Uganda and Canada

In another activity the children drew outlines of their bodies and then identified and differentiated between needs and wants. Children identified needs as healthy food, clean water, clean air, a family who loves them and wants as candy, your own room, a family vacation, extra spending money. Interestingly, play was inconsistently listed as a need, as some children associated it with wants such as computer games and toys, while others as central to exercise and learning. 


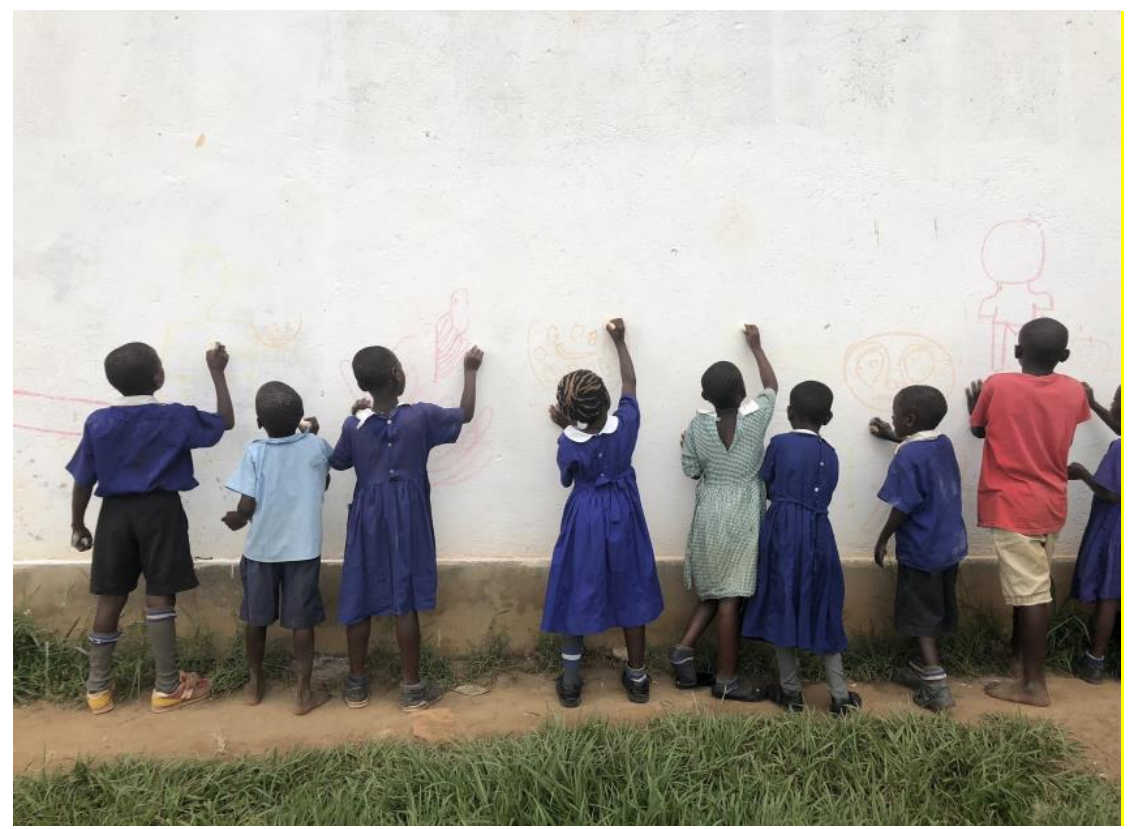

Figure 6 - Body Mapping- Needs and Wants

The discussions and group learning activities supported learning through the ZPD, as the children conversed with, shared ideas and experiences, and supported each other's learning. These activities guided students to link their individual experiences within a wider theoretical framework of children's rights, which is key to knowledge acquisition under social constructivism (Vgotsky, 1978; Young, 2007).

One of the final activities engaged children in expressing knowledge acquired through interactions with MKOs, scaffolded activities, and ZPD learning experiences through independent work. This activity was intended to support the development of the children's empowerment, "[an] individual's capacity to make effective choices ... and then transform those choices into desired actions and outcomes" (Alsop et al, 2006, p. 10), through having a voice in the larger society. The children each drew a picture of the right they deemed most important, with a note asking that their rights be respected, to be sent to their president or prime minister. This activity encouraged them to express their creative selves and articulate their democratic voice, thereby exercising their "critical agency" (Sen \& Dreze, 2002; Hart \& Brando, 2018). While the workshops did not measure outcomes, the children appeared to have achieved functionings ("beings" and "doings") in the areas of identifying, understanding, and expressing their conceptions of rights. This provided them with the freedom to act upon these functionings, enabling them to progress towards the realization of related capabilities leading to "the freedom 
to achieve various lifestyles" (Sen, 1999, p. 4). In analysing the postcards to political leaders and pictures, children reiterated a similar list of rights as ones they wished to promote. In Uganda, this included the right to good sleep and rest; be listened to, be handled properly, good health; clothing, good food, a good life, a good family, school, a good home, be beautiful, be happy, be loved by parents, safety and security, not be beaten, be free from poverty, move freely, and be free. In Canada, children noted the right to: a room or a house; a family who loves them, be safe, be able to write (and be listened to), school; healthy food, water, and clean air.

To expand the ZPD, where children in different global contexts could support each other's learning, and in the spirit of Article 29d of the UNCRC which acknowledges the importance of cultivating universal empathy and intercultural understanding of the global community through "the preparation of the child for responsible life in a free society, in the spirit of understanding, peace, tolerance, equality of sexes, and friendship among all peoples, ethnic, national and religious groups and persons of indigenous origin" (p.1), the MKOs invited the children in Uganda and Canada to communicate with each other, class-to-class.

The Ugandan children first sent letters and drawings to the children in Victoria.
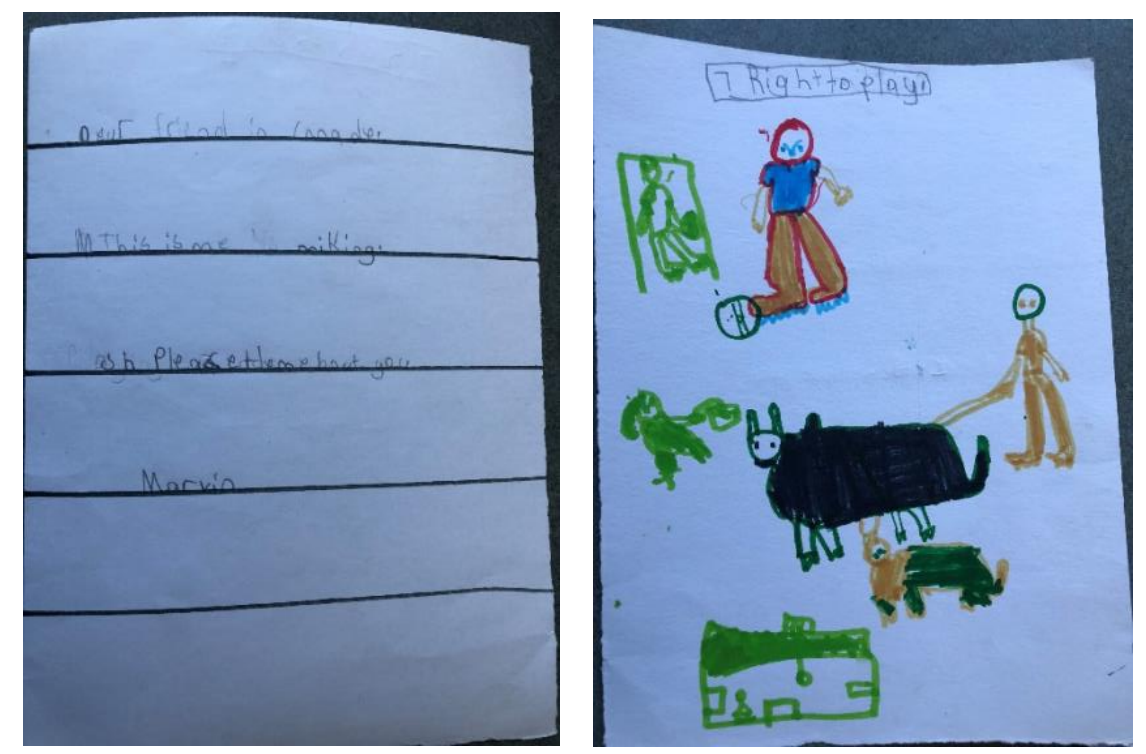

Figure 7 - Letters from Uganda to Canada 
They also had the following questions for the Canadian children:

1. Are children normally taught in school or home how to be open or straight when it comes to their rights?

2. Are jobs and responsibilities chosen for the kids and depending on gender?

3. How about home chores, are they done according to gender?

4. How about when children's rights are violated, how are kids helped and what happens to the culprit?

Once the first correspondence was received, the children in Victoria clearly considered the questions and processed what the children in Uganda asked. This provided them a greater understanding of the various roles, responsibilities, realms, and components of rights in their own lives.

The final question, "How about when children's rights are violated, how are kids helped and what happens to the culprit?" raised interesting considerations and inquiry for the MKOs as well as the children, demonstrating a powerful moment of colearning (that violations of children's rights is a problem), coinquiry (what is known about the violation of children's rights in global and local contexts), and coreflection (when/how/where/why or why not is the topic of the violation of children learned about and addressed in school) (discussed further below). The ZPD that was established through the children's correspondence and discussion led to much coconstructed and experiential learning within the social constructivist framework. We have identified these below.

\section{On Contexts}

A social constructivist approach to education acknowledges that culture, language, home and family, and lived experience constitute foundational knowledge upon which new knowledge will be acquired. Thus, encouraging children to consider and express what is known and familiar to them demonstrates what they know, think, and can do is worth sharing with others. Sharing amongst peers is core to ZPDs. For instance, the Ugandan children drew pictures of rural domestic life, including milking a cow, taking a school bus to school, or cooking over a fire. The Canadian children drew images related to their environments based on urban life, including houses, schools, parks, and playgrounds. Both demonstrated the integrated critical insights children provided regarding their rights and needs embedded within their given contexts and 
their understanding of their right to access those rights, such as access to education. In comparing each other's experiences, the Canadian children noted they were more likely to learn about their rights at school than at home, yet they also highlighted that their needs were met and rights adhered to at home. The children in both contexts also articulated that they were intent on having their ideas heard and acknowledged.

The class-to-class correspondence illustrated their curiosity about one anothers' homes and communities, including, for example, in what order are family and given names written/said; are the rules of games like football and baseball the same; what are houses made of; at what age do children complete elementary school; how many students are in one class; how do children get to school; at what age do children begin working; do homes have televisions/power. These questions demonstrate genuine engagement with learning and curiosity about the lives of other children and a desire to understand diverse cultures, contexts, and experiences - the foundations of empathy.

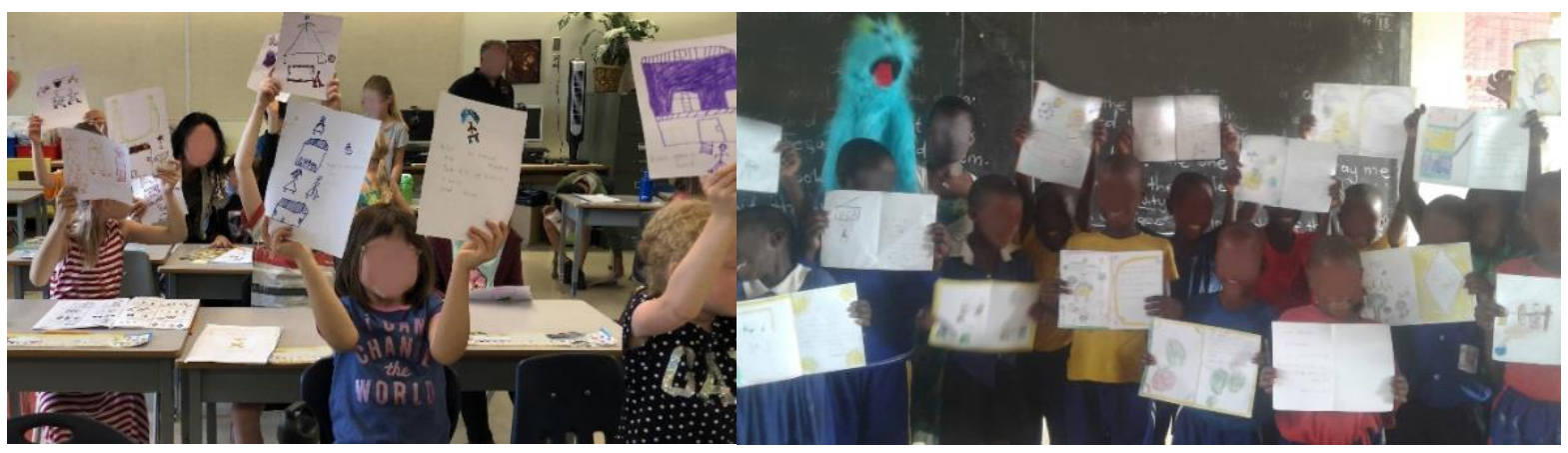

Figure 8 - Children Sharing Rights with Each Other - Canada and Uganda

\section{Different priorities and experiences}

The MKOs' knowledge was also deepened through the analysis of the children's diverse responses, inquiries, and correspondence with each other. In this way the MKOs and the children cocreated new knowledge. For example, children in Canada focused on more environmental rights, including the right to clean air and clean water, than did the children in Uganda. This raised questions about whether this related to the fact that there was more of an emphasis on environmental education in the Canadian curriculum or the urban Canadian children lived in an urban setting with industrial or vehicular pollution, whereas the rural Ugandan children did not, or some other reason. 
Gender was another topic where differences in understanding and experiences surfaced. The Ugandan children asked the Canadian children to highlight the differences between roles and opportunities for girls and boys. The children in Canada seemed bemused by the question and responded that they did not think there were differences either at home or at school. While the right to nondiscrimination was discussed in the workshop, the children did not highlight gender equality as a critical right in either their drawings or discussions. However, when the question was raised, more reflection emerged. An example question was "Are home chores [for children] done according to gender?" Within the Ugandan context, it was intimated that gender roles were more clearly delineated, with female roles aligned with the home (e.g. sweeping, cooking, cleaning the house, washing dishes, looking after younger children, fetching water) and male roles affiliated outside the home (e.g., feeding and herding animals and running errands into trading centres or nearby towns). These concepts are also well documented in the literature where problematic gender inequality has been identified (Blackden, 2004; Bantebya et al, 2014; Jones, 2008, 2011, 2018; Uganda Ministry of Gender, Labour, and Social Development, 2007; Uganda Ministry of Education and Sports (MOES), 2015; UNDP, 2015). The Uganda MOES (2013) has identified the educational barriers that domestic burdens place on female children. Within the Canadian context, gender inequality certainly does exist in Canada, but the children did not note it possibly because it is less starkly observed. This suggests that these basic discussions of gender equality will constitute background knowledge for further discussion and more nuanced and sophisticated consideration of the topic at a later stage. Again, children placed a specific, experiential question within the context of lived experience within a wider theoretical framework $f$ gender equality.

When asked about circles of protection, children in both settings identified family members as protectors, i.e. their mothers, fathers, siblings, grandparents, and other family members, their teachers, and themselves. The Canadian children, however, also identified a wider array of support people, including nurses, doctors, police officers, firefighters, and politicians, whereas the Ugandan children did not. There is a range of potential reasons for this, including the perceived or actual roles of other "protectors" within public and civic institutions. In asking "How about when children's rights are violated, how are kids helped and what happens to the culprit?" the Ugandan children highlighted the openness and prevalence of violence against children in their setting. The teacher veered the Canadian children to interpret the 
question in a way that would make sense in their context, i.e. bullying in school. A further exploration of this question highlighted who children would turn to for help and the children reiterated those individuals identified in their circles of protection (i.e. teachers, parents, siblings, peers, other school staff, police). This illustrated their openness to explore how to understand rights violations and question how they are redressed.

The children in Uganda asked questions about more overt rights violations from minor through to criminal that included "violence ranging from beating, starving, failure to be taken to school, early/forced marriage, child labour, etc. ... victims of domestic violence by drunk parents, prostitutes etc.” (personal communication, Teacher in Uganda). To triangulate this, Child et al (2014), Clarke et al (2016) and Rwanyonga et al (2009) note the high prevalence of serious violations of children's rights, including sexual, physical and emotional abuse, abandonment and neglect, and poverty (leading to food and housing insecurity), as well as a dearth of effective interventions for these violations. While fundamental breaches of rights happen in both settings, this illustrates the more hidden nature of violence against children in the Canadian context but also a discomfort for discussing difficult gross violations within a classroom, with more comfort and familiarity with addressing issues like bullying and behavioural issues.

\section{Broader Insights from other children}

While this represented a small study, insights from the workshops that have been happening since 2014 suggest that elementary school-aged children from as early as kindergarten have personal knowledge and experience of children's rights, particularly survival rights (e.g. shelter, food, water, family, clean air). They also recognise the circles of protection in their lives and in other children's lives, as well as the difference between rights and responsibilities, and needs and wants. They also discern injustices and unfairness that happens in their own context. Children in later grades are also aware of injustices in other countries too. With a social constructivist approach to rights-based education they can learn how to identify, articulate, and expand their knowledge of their and others' rights and responsibilities, which will both empower them and increase their critical agency to exercise their capabilities.

In exploring rights and responsibilities in participatory, inquiry-based, child-centred, collaborative, and supportive learning environments, with MKOs and age-appropriate and contextually relevant resources, children can better understand the systems, structures, processes, 
and sociocultural dimensions of their local context including relevant protective institutions, services, professionals, authorities, groups, and individuals. Child-rights education needs to leave space for this cocreative dialogue on rights as interpreted by children within their own context.

\section{Conclusion}

This paper has built upon the argument that a social constructivist approach to children'srights education supports both the empowerment of children and the cultivation of important capabilities whilst also embodying key pillars of the UNCRC itself.

Increasingly, over the past couple of decades, adults have expressed concern for the world we are leaving our children, their children, and generations to come. We, as adults, have acknowledged that decisions we make, as well as decisions made by our parents and grandparents in their adult lives, have coalesced to bring the world to its current state of multiple crises, including (but not limited to) climate change, species extinction, COVID-19 pandemic, hunger, and lack of respect for human rights. We now have the responsibility to ensure that children are empowered with the knowledge, skills, and capabilities they need to make the big decisions that will have to be made to preserve the planet. Children have the right to consider and make choices about their futures, and they have the right to know about the rights that they hold to make these decisions.

As an undercurrent, children's-rights education helps with the conscientization (Freire, 1970) of their rights and responsibilities and building critical consciousness and community responsibility. Recognising and emphasizing the binding nature of rights and responsibility provides an important basis for citizenship (Covell \& Howe, 2012; Jones \& Walker, 2011; Byrne \& Lundy, 2015). People often underestimate children's ability to understand issues like rights (Lundy, 2012; Manion \& Nixon, 2012; Bissell et al, 2012), but the case study illustrates their sophisticated colearning. This is in keeping with Friere's call for overhauling the education system and can align with rights and their corresponding responsibilities and the role teachers can have in supporting a more exploratory and immersive experience.

In exploring how rights-based education can be integrated with curricular objectives, with supportive synergy in areas like student citizenship, literacy, and civic understanding, this paper proposes that this can be achieved by underpinning empowerment and capabilities through social constructivist education. This paper proposes a model that supports children to critically reflect 
on what children need to survive and thrive and how they can support other children. This explores how Child Thrive interacts with, responds to, builds on, and furthers curriculum, illustrating how it can be further integrated into classrooms (as has been done in some classes in both Uganda and Canada). The multimodal approach enables different kinds of ways to communicate (e.g. drama, speaking, and drawing) to allow different talents and perspectives to emerge in child-friendly, participatory ways. The case study illustrates how some children identified their understanding of their rights and responsibilities, their needs, wants, and circles of support but also a keenness to know more. It underscored the universality of the fundamental values of empathy, justice, love, dignity, equality, support, and protection that constitute children's rights. This provided an impetus to further this work and deepen the approach to children's-rights education. 


\section{References}

Adams, P. (2006). Exploring social constructivism: Theories and practicalities. Education, 34(3), $243-257$.

Alderson, P. (2008). Young Children's Rights: Exploring Beliefs, Principles and Practices (2nd ed). London, England: Jessica Kingsley.

Alsop, R., Bertelsen, M., \& Holland, J. (2006). Empowerment in practice from analysis to implementation. Washington, DC: World Bank.

Ashiabi, G.S. (2007). Play in the Preschool Classroom: Its Socioemotional Significance and the Teacher's Role in Play. Early Childhood Education Journal, 35(2), 199-207.

Bantebya, G.K., Muhanguzi, F.K., \& Watson, C. (2014). Adolescent girls in the balance: Change and continuity in social norms and practices around marriage and education in Uganda. London, England: Overseas Development Institute.

Biddle, S.K. (2017). Social Constructions of Childhood: From Not-Yet-Adults to People in Their Own Right. Anthós, 8(1), 3.

Bissell, S., Boyden, J., Cook, P., \& Myers, W. (2012). Rethinking Child Protection from a Rights Perspective: Some Observations for Discussion (Draft). Retrieved from http://www.iicrd.org/resources/research_reports/ICPRC1

Blackden, C.M. (2004). Out of control: Gender and poverty in Uganda. A strategic country gender assessment (Discussion draft). Washington, D.C., U.S.: World Bank.

Blackstock, C., Bamblett, M., and Black, C. (2020). Indigenous ontology, international law and the application of the Convention to the over-representation of Indigenous children in out of home care in Canada and Australia. Child Abuse \& Neglect Advance online publication. Retrieved from https://doi.org/10.1016/j.chiabu.2020.104587.

Boydell, N., Nalukenge, W., Siu, G., Seeley, J., \& Wight, D. (2017). How mothers in poverty explain their use of corporal punishment: a qualitative study in Kampala, Uganda. The European journal of development research, 29(5), 999-1016.

Boyden, J., \& Ennew, J. (1997). Children in Focus - a manual for participative research with children. Stockholm, Sweden: Radda Barnen.

Bradshaw, J. (2016). The Well-being of Children in the UK (4th Edition). Bristol, England: Bristol Press. 
Brady, G., Lowe, P. \& Lauritzen, S.O. (2015). Connecting a sociology of childhood perspective with the study of child health, illness and wellbeing: introduction. In G.M. Brady, P. Lowe, \& S. Olin-Lauritzen (Eds). Children, health and well-being: Policy debates and lived experience. Hoboken, New Jersey, U.S.: Wiley-Blackwell.

Britto, Pia R et al. (2016). Nurturing care: promoting early childhood development. The Lancet, 389(10064), 91-102.

Bronfenbrenner, U. (1986). Ecology of the family as a context for human development: Research perspectives. Developmental Psychology, 22(6), 723-742.

Burridge, N. \& Chodkiewicz, A. (2017). Educating teachers about human rights: building a rights based culture in Australian schools. Asia-Pacific Journal of Teacher Education, 45(5), 455-468. Retrieved from DOI: 10.1080/1359866X.2016.1201044

Butler, C. (2012). Child rights: The movement, international law, and opposition. West Lafayette, IN: Purdue University Press.

Byrne, B. \& Lundy, L. (2015). Reconciling children's policy and children's rights: Barriers to effective government delivery. Children \& Society, 29(4), 266-276. Retrieved from DOI: 10.1111/chso. 12045

Cheung, C. (2016). Integrating a Rights-Based Approach in Ontario Elementary Classrooms. Unpublished MA thesis,. Department of Curriculum, Teaching and Learning, Ontario Institute for Studies in Education at the University of Toronto.

Child, J.C., Naker, D., Horton, J., Walakira, E.J., \& Devries, K.M. (2014). Responding to abuse: children's experiences of child protection in a central district, Uganda. Child abuse \& neglect, 38(10), 1647-1658.

Christensen, P. \& James, A. (2000). Researching children and childhood: Cultures of communications. In P. Christensen \& A. James (Eds.). Research with children: Perspectives and practices (pp. 1-8). Brighton, England: Falmer Press.

Christensen, P. \& Prout, A. (2002). Working with ethical symmetry in social research with children. Childhood, 9(4), 477-497.

Clarke, K., Patalay, P., Allen, E., Knight, L., Naker, D., \& Devries, K. (2016). Patterns and predictors of violence against children in Uganda: a latent class analysis. BMJ open, 6(5), $\mathrm{e} 010443$.

Collins, T. (2017). A child's right to participate: Implications for international child protection. The International Journal of Human Rights, 21(1), 14-46. Retrieved from DOI: $\underline{10.1080 / 13642987.2016 .1248122}$ 
Collins, T. \& Wright, L. (2019). Advancing the Right to Play in International Development. In C. Fenton-G1

nn (Ed.). Children's Rights and Sustainable Development: Interpreting the UNCRC for Future Generations (Treaty Implementation for Sustainable Development, pp. 306-336).

Cambridge, England: Cambridge University Press. Retrieved from

DOI:10.1017/9781108140348.014

Covell, K. \& Howe, R.B. (2012). Developmental Considerations in Teaching Children's Rights. In C. Butler (Ed). Child rights: The movement, international law, and opposition. Lafayette, IN: Purdue University Press, pp. 37-54.

Covell, K., Howe, R.B., \& McGillivary, A. (2017). Implementing children's education rights in schools. In M.D. Ruck, M. Peterson-Badali, \& M. Freeman (Eds.). Handbook of children's rights: Global multidisciplinary perspectives. Abingdon, Oxfordshire, England: Routledge.

Creswell, J. (2015). Educational Research Planning, Conducting, and Evaluating Quantitative and Qualitative Research. New York, U.S.: Pearson.

Creswell, J. \& Creswell, D.J. (2018). Research Design: Qualitative, Quantitative, and Mixed Methods Approaches (5th ed). London, England: SAGE Publishing.

Currie, V. \& Heykoop, C. (2011). Circle of Rights: Intentional Planning for Social Change Manual. Victoria, Canada: International Institute for Child Rights and Development.

Devries, K.M., Child, J.C., Allen, E., Walakira, E., Parkes, J., \& Naker, D. (2014). School violence, mental health, and educational performance in Uganda. Pediatrics, 133(1), e129e137.

Equitas International Centre for Human Rights Education (2008). Play it Fair, Human Rights Education Toolkit for Children. Author.

Frankel, S. (2012). Children, morality and society (Studies in childhood and youth). London, England: Palgrave Macmillan.

Freeman, M. (2011). Why It Remains Important to take Children's Rights Seriously. In M.

Freeman (Ed.). Children's rights: progress and perspectives - essays from the international journal of children's rights. Retrieved from http://ebookcentral.proquest.com

Freire, P. (1972). Pedagogy of the Oppressed. Harmondsworth, Eng. ; New York: Penguin Books

Geertz, C. (1973). The Interpretation of Cultures. New York, U.S.: Basic Books.

Grbich, C. (2013). Qualitative data analysis: An introduction (2nd ed.). London, England: Sage. 
Hanlon, R. \& Christie, K. (2016). Freedom from fear, freedom from want: An introduction to human security. Toronto, ON: University of Toronto Press.

Hart, C. \& Brando, N. (2018). A capability approach to children's well-being, agency and participatory rights in education. European Journal of Education, 53(3), 293-309.

Hines, M.B., Armbruster, K., Henze, A., Lisak, M. Romero-Ivanova, C., Rowland, L., \& Waggoner, L. (2016). Action research in education. Oxford Bibliographies. Retrieved from DOI: 10.1093/OBO/9780199756810-0140

Howe, B. \& Covell, C. (2013). Education in the Best Interests of the Child: A Children's Rights Perspective on Closing the Achievement Gap. Toronto, ON: University of Toronto Press. Hughes, F.P. (2010). Children, play, and development (4th ed.). London, England: Sage. Ibrahim, S. \& Alkire, S. (2007). Agency and empowerment: A proposal for internationally comparable indicators. Oxford Development Studies, 35(4), 379-403. Retrieved from DOI $10.1080 / 13600810701701897$

Jones, D. (2002). Listening to children. Child Abuse \& Neglect, 26(8), 833-835.

Jones, P. \& Walker, G. (Eds.). (2011). Children's rights in practice. London, England: Sage.

Jones, S. \& Manion, H.K. (2019). Child Thrive: Building child rights understanding one child at a time: Ugandan and Canadian Primary School Students' Ideas, Comparative and International Education Society of Canada, Congress 2019, UBC, Vancouver June 2019.

Jones, S. (2011). Girls' secondary education in Uganda: Assessing policy within the Women's Empowerment Framework. Gender and Education, 23(4), 385-413.

Jones, S. (2018). Educators' explorations with gender performativities and orientations: A participatory action research project in West Nile Sub-Region, Uganda. Language and Literacy, 20(4), 55-77.

Jones, S. (2019). Report for Uganda National Council of Science and Technology. Protocol SS 4628: Exploring Ugandan Primary School Students' Understanding of the Importance of Children's Rights in their Lives. (June 17, 2019). Submitted to the Uganda National Council of Science and Technology.

Jones, S., Manion, H.K., \& Mack, E. (2019). Importance of Children's Rights: Perspectives from Ugandan and Canadian Primary School Students. 14th Annual Education and Development Conference, Bangkok, Thailand, March 6, 2019. Retrieved from https://www.researchgate.net/publication/331963186_Students_14th_Annual_Education_and _Development_Conference_5th_-7th_of 
Jones, S.K. (2008). Secondary schooling for girls in rural Uganda: Challenges, opportunities, and emerging identities. Doctoral dissertation, University of British Columbia, Vancouver, Canada. Retrieved from https://circle.ubc.ca/handle/2429/279?show=full

Kalina, C. \& Powell, K.C. (2009). Cognitive and social constructivism: Developing tools for an effective classroom. Education, 130(2), 241-250.

Kozulin, A. (1990). Vygotsky's psychology: A biography of ideas. Cambridge, M.A., U.S.: Harvard University Press.

Lansdown, G. (2009). A framework for measuring the participation of children and adolescents. UNICEF MENA Regional Office. Retrieved from www.childrightsinpractice.org/forum/topics/measuring-childparticipation

Lansdown, G. (2011). Every child's right to be heard: A resource guide on the UN Committee on the Rights of the Child General Comment No. 12. London, U.K.: Save the Children/United Nations Children's Fund.

Lester, S. \& Russell, W. (2008). Play for a Change. London, U.K.: National Children's Bureau. Lester, S. \& Russell, W. (2010). Children's Right to Play: An Examination of the Importance of Play in the Lives of Children Worldwide. Working Papers in Early Childhood Development, No. 57. The Hague, Netherlands: Bernard van Leer Foundation.

Levine, P. \& Youniss, J. (2009). Introduction Policy for Youth Civic Engagement. In L. Hamilton, P. Levine, \& J. Youniss (Eds.). Engaging young people in civic life. Nashville, U.S.: Vanderbilt University Press. Retrieved from http://public.eblib.com/choice/publicfullrecord.aspx?p=3040004

Lundy, L. (2007) "Voice is not enough": Conceptualising Article 12 of the United Nations Convention on the Rights of the Child, British Education Research Journal, 33(6) 927-942.

Lundy, L. (2012). Children's rights and educational policy in Europe: The implementation of the United Nations Convention on the Rights of the Child. Oxford Review of Education, 38(4), 393-411. Retrieved from DOI:10.1080/03054985.2012.704874

Macdonald, D. \& Wilson, D. (2013). Poverty or Prosperity: Indigenous Children in Canada. Ottawa, Canada: Centre for Policy Alternatives \& Save the Children Canada.

Manion, H.K. \& Jones, S. (2019). Importance of Children's Rights: Perspectives from Ugandan and Canadian Primary School Students. 14th Annual Education and Development Conference, Bangkok, Thailand, March 6, 2019. 
Manion, K. \& Nixon, P. (2012). Listening to experts: Children and young people's participation. Social Work Now, 49(February), 30-39.

Mason, J. (2002). Qualitative Researching (2nd ed.) London, England: Sage.

Miles, M. \& Huberman, A. (1994). Qualitative Data Analysis (2nd ed.). London, England: Sage. Milner, H. (2009). Youth electoral participation in Canada and Scandinavia In L. Hamilton, P. Levine, \& J. Youniss (Eds). Engaging Young People in Civic Life. Tennessee, U.S.: Vanderbilt University Press. Retrieved from http://public.eblib.com/choice/publicfullrecord.aspx?p=3040004

Milner, P. \& Carolin, B. (1999). Time to listen to children: Personal and professional communication. Abingdon, Oxfordshire, England: Routledge. Retrieved from http://public.eblib.com/choice/publicfullrecord.aspx?p=166066

Muhanguzi, F.K. (2011). Gender and sexual vulnerability of young women in Africa: experiences of young girls in secondary schools in Uganda. Culture, Health \& Sexuality, 13(06), 713-725.

Niemi, R.G., \& Junn, J. (1998). Civic education: What makes students learn. Bellevue, WA, U.S.: Yale University Press. Retrieved from

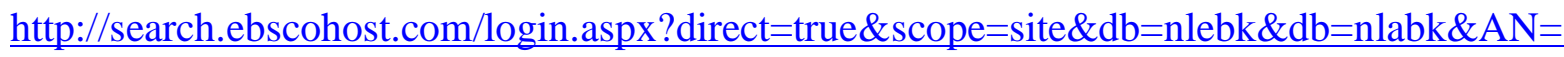
$\underline{52882}$

Nixon, P. (2002). Children at the center? Enhancing children's participation in family decision making. Presentation at the Family Group Decision Making Roundtable, Asilomar State Park, Pacific Grove, CA.

Normand, R. \& Zaidi, S. (2008). Human rights at the UN: The political history of universal justice (United Nations intellectual history project). Bloomington, Indiana, U.S.: Indiana University Press.

NRC (National Research Council) (U.S.) \& Institute of Medicine (U.S.). (1996). Paying attention to children in a changing health care system: Summaries of workshops. Washington, DC: National Academies Press.

NRC (National Research Council) (U.S.), Allen, L., \& Kelly, B.B. (2015). Transforming the workforce for children birth through age 8: A unifying foundation. Washington, DC: National Academies Press.

Nussbaum, M. (2003). Women's education: a global challenge. Signs: Journal of Women and Culture in Society, 29(2), 325-355. Retrieved from DOI: 10.1086/378571. 
Nussbaum, M. (2011). Creating capabilities. The human development approach. Cambridge, MA: Harvard University Press.

Piaget, J. (1962). Play, dreams and imitation. New York, U.S.: Norton.

Reason, P. \& Bradbury, H. (2006). Handbook of Action Research. London, England: Sage.

Ruiz-Casares, M., Collins, T., Tisdall, K., \& Grover, S. (2017). Children's rights to participation and protection in international development and humanitarian interventions: nurturing a dialogue. The International Journal of Human Rights, 21(1), 1-13. Retrieved from DOI: $\underline{10.1080 / 13642987.2016 .1262520}$

Rwanyonga, T.C., Mike, M., \& Nakubulwa, A. (2009). Child Sexual Abuse in Schools: Preliminary Indication for Enhancement of Universal Primary Education and Community (EUPEC Project) - Uganda. Journal of Psychology in Africa, 19(1), 103-106.

Saito, M. (2003). Amartya Sen's capability approach to education: A critical exploration. Journal of Philosophy of Education, 37(1), 17-3. Retrieved from DOI: 10.1111/14679752.3701002 .

Save the Children (2008). The Child Development Index: Holding governments to account for children's wellbeing. London, U.K.: Author.

Sen, A.K. (1999). Development as Freedom. New York, U.S.: Alfred Knopf.

Sen A.K., (2000). Social Exclusion: Concept, Application, and Scrutiny, Social Development Paper, Manila, Philippines: Asian Development Bank.

Sen, A.K. (2005). Human rights and capabilities. Journal of Human Development, 6(2), 155166. Retrieved from DOI: 10.1080/1464988050012049.

Sen, A.K. \& Dreze, J. (2002). India: Development and participation. Oxford, England: Oxford University Press.

Shamrova, D. \& Cummings, C. (2017). Participatory Action Research (PAR) with children and youth: An integrative review of methodology and PAR outcomes for participants, organizations, and communities. Children and Youth Services Review, 81(2017), 400-412.

Shier, H (2001). Pathways to Participation: Openings, Opportunities and Obligations. Young People and Society, 15, 107-117.

Silcock, P. (2003) Accelerated learning: a revolution in teaching method? Education, 3-13, $31(1), 48-52$. 
Souto-Manning, M. (2017). Is play a privilege or a right? And what's our responsibility? On the role of play for equity in early childhood education. Early Child Development and Care, 187(5-6) 785-787.

Sutherland, R., Armstrong, V., Barnes, S., Brawn, R., Breeze, N., Gall, M., Matthewman, S., Olivero, F., Taylor, A., Triggs, P., Wishart, J., \& John, P. (2004) Transforming teaching and learning: embedding ICT into everyday classroom practices, Journal of Computer Assisted Learning, 20, 413-425.

Tibbitts, F. (2002). Understanding what we do: Emerging models for human rights education. International Review of Education, 48(3-4), 531-549.

Torre, M.E., \& Fine, M. (2006). Participatory action research (PAR) by youth. Youth activism: An international encyclopedia, 2, 456-462.

Ministry of Education and Sports (MOES), Uganda (2015). National Strategy for Girls' Education. Kampala, Uganda: Author. Ministry of Gender, Labour, and Social Development (MoGLSD) (2007). The Uganda gender policy. Kampala, Uganda: Author.

Unger, M. (2009). Resilience practice in action: Five principles for intervention, Social Work Now, 43(August), 32-38.

UNICEF (2017). Report Card 14: Child Well-being in a Sustainable World. Florence: Innocenti. UNICEF (2017). UNICEF State of the World's Children 2017. Florence: Innocenti.

UNICEF Canada (2016). Fairness for Children: UNICEF Report Card 13. Florence: Innocenti. UNICEF Canada (2018). The Equalizer: How Education Creates Fairness for Children in Canada: UNICEF Report Card 15. Florence: Innocenti.

UNICEF Canada (2019). Where Does Canada Stand? The Canadian Index of Child and Youth Well-being 2019 Baseline Report. Florence: Innocenti.

United Nations Committee on the Rights of the Child (CRC). (2001). General comment No. 1, Article 29 (1), The aims of education, CRC/GC/2001/1. Retrieved from https://www.refworld.org/docid/4538834d2.html

United Nations Convention on the Rights of the Child (UNCRC). (1989). UN General Assembly. Retrieved from http://www.ohchr.org/Documents/ProfessionalInterest/crc.pdf

Verhellen, E. (1994). Convention on the Rights of the Child: background, motivation, strategies, main themes. Leuven, Belgium: Garant.

Vygotsky, L.S. (1978). Mind in society. Cambridge, M.A., U.S.: Harvard University Press. 
Wabwile, M.N. (2016). Realising Children's Economic and Social Rights: Towards RightsBased Global Strategies. In M. Ruck, M. Peterson-Badali, \& M. Freeman (Eds). Handbook of Children's Rights: Global and Multidisciplinary Perspectives. Milton Park, Abingdon, U.K.: Taylor \& Francis.

Waldfogel, J. (2004). A cross-national perspective on policies to promote investments in children. In A. Kalil \& T. DeLeire (Eds.). Family investments in children's potential: Resources and parenting behaviors that promote success. London, England: Psychology Press.

Wodon, Q., Nguyen, M.C., \& Tsimpo, C. (2016). Child marriage, education, and agency in Uganda. Feminist Economics, 22(1), 54-79.

Young, M. (2007). Bringing knowledge back in: From social constructivism to social realism in the sociology of education. Abingdon, Oxfordshire, England: Routledge. 